\title{
The Portrait of Mothers and Fathers in Croatian Daily Newspapers and in a Magazine for Parents: Today and Twenty Years Ago
}

\author{
Tea Pahić and Renata Miljević-Riđički \\ Faculty of Teacher Education, University of Zagreb
}

\section{Abstract}

The aim of the present study was to examine whether there has been a change in the representation of fathers and mothers in the Croatian press over the last twenty years. In particular, we wanted to examine how mothers and fathers have been presented in daily newspapers and a magazine for parents, and whether the current trend towards a greater involvement of fathers in raising children is noticeable in the Croatian press. In order to answer the research question we conducted a content analysis of two daily newspapers, and one magazine for parents. The obtained results show that the public image of the roles of mother and father has somewhat changed in the last twenty years. Although fathers have increasingly been shown as co-parents, it is obvious that we are still in a transition period with a number of ambivalences and contradictions regarding the role of the fathers.

Key words: Croatian daily newspapers; Croatian periodical newspapers; presentations of fathers; presentations of mothers.

\section{Introduction}

Although there are many different explanations of the terms mother and father, the common definition of mother and father is that they represent persons who raise children. However, their roles in the upbringing of children differ. In most of the dominant cultures, the mother is traditionally seen as the person who cares for and nurtures the children while the father is the breadwinner and support to mother.

Mothers are seen as primary caregivers (Cabrera et al., 2000) while fathers have a secondary role with less impact on children's development (Cabrera et al., 2000; 
Newland \& Coyl, 2010). Sometimes fathers are described as the "forgotten parent" (Rudan \& Nikolić, 1998). According to the perception of gender differences, mothers are usually perceived as gentle and sensitive while fathers are strong, brave and determined (Biller, 1993).

Still, recent cross-cultural studies suggest that there is a change in these roles, in the sense that fathers are increasingly directly involved in raising and caring for children (Biller, 1993; Parke, 1996; Pleck, 1997; Clark \& O’Brien, 2004; Gray \& Anderson, 2012). As Randal and Mackey (1986) suggest, before the 1970s fathers in western societies were generally seen as incompetent in terms of taking care of young children. The media usually portrayed them in a humorous manner as clumsy, thoughtless and inefficient in providing care. After this period, due to the considerable presence of women at the labour market and changed relationships between men and women, the image of fathers in the public eye has changed and they have started to be seen as a fairly effective mother substitute (Castelan-Meunier, 2012). Actually, it seems that at a certain point, fathers have obviously become recognized as potentially effective and important persons in the social and emotional development of children. Therefore we are interested in whether there has been a change in the representation of mothers and fathers in the press over the last twenty years, and, if so, whether the observed changes follow the direction which recent studies of maternal and paternal childcare suggest. In particular, we wanted to examine how daily newspapers and a magazine for parents present mothers and fathers, and whether the current trend towards the greater involvement of fathers is noticeable in the Croatian press. Considering the fact that the media have a great impact on the way we see the world and influence the formation of social opinions, we aimed to examine what kind of explicit or implicit messages about mothers and fathers they embody, and to discuss their possible effect.

\section{The Aim of the Research}

The aim of the research was to examine the way in which Croatian daily newspapers and a magazine for parents depict mothers and fathers, and whether there is a difference in their presentations today and twenty years ago.

\section{Problems}

1. To determine the frequency of articles which contain the word mother and father with respect to the type and the year of publication of the magazine.

2. To examine whether the portraits of mother differ from the portraits of father regarding their positive, negative and neutral presentations with respect to the type and the year of publication of the magazine, and to discuss the content of articles in which they are mentioned.

\section{Hypotheses}

1.We assumed that the word mother would be mentioned more often than the word father in all three magazines regardless of the year of publication. In addition, we 
assumed that the word mother would be mentioned more often in the headlines and would occur more often than the word father on the front cover of the papers. Also, we assumed that in comparison with a relative frequency of mentioning mothers, the relative frequency of mentioning fathers would have increased in today's newspapers as a sign of an increasing involvement of fathers.

2. We assumed that mothers would be presented in a positive manner more often than fathers, while fathers would be presented in a negative manner more often than mothers, regardless of the type and year of publication of the paper.

\section{Method}

\section{Sample}

We have analyzed two daily newspapers, Večernji list and Vjesnik, published in the years 1991 and 2011, and a magazine for parents Bebe published in 1992 and 2012. The unit of analysis represents all the issues of the two newspapers in the years 1991 and 2011, and the first twelve issues of the monthly magazine published in the year 1992/93 and all twelve issues in the year 2012.

\section{Newspaper Selection Rationale}

We have selected Večernji list because, according to the poll conducted by "Gfk Market Research Center" in 2011, it was one of the most popular daily newspapers in Croatia (Večernji list, 2012). Večernji list is mildly tabloid oriented with the focus on news of interest to the ordinary citizens and has a circulation of more than 70,000 copies.

Vjesnik was a political journal, published in the period from 1945 to 2012. It was also the oldest and one of the most widely read daily newspapers as well as the first daily online newspaper since 1998. Although the contents of Vjesnik mostly covered political and economic events in the country and the world, and its target group was mainly the people who wanted to get the relevant information about the socio-political events (Vodopija, 2006), this paper also published articles about everyday life issues and new scientific knowledge in the country and the world. In 2012 when it shut down, Vjesnik had a circulation of 10,000 copies.

The first issue of Bebe, a monthly magazine for parents and expecting mothers was published in May 1992. It is the first Croatian magazine that gives parents comprehensive information on the health and education of children of early and preschool age, and the target group of readers are parents with small babies or those who are expecting a baby. Experts in the field of children's health and education contribute articles to the journal and a circulation of 8,000 copies makes it the bestselling magazine in this narrowly specialized field in Croatia (Bebe, 2011).

\section{Procedure}

The newspaper and magazine analysis was carried between September 2012 and April 2013, in the City Library "Metel Ožegović" in Varaždin and the National University Library (NUL) in Zagreb. 
Although the initial intention was to conduct the content analysis of the articles containing the word mother and/or father in the title, the preliminary review of the newspapers showed that titles often had nothing to do with the content of the text itself. Therefore, we decided to conduct a detailed inspection of all the articles in the papers and register the number of articles that contained words mother and/or father. We recorded the frequency of the word mother and its synonyms (e.g. mom, mama, mum, mammy) as well as the frequency of the word father and its synonyms (e.g. dad, daddy, papa, pop, poppa). In addition, we counted how many times the word mother and/or father appeared in the article title or at the front cover of the paper. Using the content analysis, we examined the manner in which mothers and fathers were portrayed in the article. We then categorized depictions of mothers and fathers into three categories, i.e. positive, negative and neutral. The positive category assumes that mothers' or fathers' description or mention in the article contains adjectives or verbs that indicate their positive traits or behaviours (e.g. "Her mother always believes in her"; "He (father) is always there to help her"; "She cannot forget her (mother's) tenderness"; "His father was proud of him", etc.). The negative category assumes that mothers or fathers in the article are described by adjectives or verbs that indicate their negative traits or behaviour (e.g. "Daughters do not go to school because their fathers do not allow them to"; "Her unscrupulous mother wanted her to "marry for money"; "Father threw the child through the window"; "Mother knew that he abused her sexually and she never stopped him"). The neutral category refers to mentioning mothers and/or fathers with no obvious description of their positive or negative traits or behaviours (e.g. "Her mother was a teacher"; "Fathers can use maternity leave"; "Mothers are now allowed to stay with their children in hospital"; "We did not get any explanation why Igor and his father did not come"). In a number of articles both mothers and fathers are mentioned, sometimes both in a positive or negative manner, and sometimes one of them in a positive and the other in a negative or neutral manner, so coding was conducted accordingly (e.g. "She (mother) does not allow him (father) to see his children"). Only a few articles depicted either mother or a father in both positive and negative manner. That would make the fourth category, which we have omitted from the analysis because the number of such cases was negligible; however, we considered these articles in counting the frequency of appearance of the words mother and father. The words father and mother symbolically used, like in "father of the homeland"; "mother of knowledge" have not been included in the analysis.

\section{Results and Discussion}

As shown in Table 1, mothers were mentioned more frequently than fathers in all publications from our sample. Mothers and fathers were almost two times more frequently mentioned in Večernji list in 2011 than twenty years before although the proportion of their mentioning does not differ statistically ( $\chi 2$ test $=3.578, \mathrm{df}=1$, $\mathrm{p}>$.05). Although Vjesnik in 2011 seemed to contain fewer articles which mentioned mothers and more articles which mentioned fathers, compared to 1991, this difference 
is not statistically significant ( $\chi 2$ test $=3.552, \mathrm{df}=1, \mathrm{p}>.05$ ). Bebe magazine in 2011 showed a tendency of a smaller number of articles which mentioned words father and mother, but as for the other magazines the proportion of mentioning does not differ significantly ( $\chi 2$ test $=2.176, \mathrm{df}=1, \mathrm{p}>.05$ ).

Table 1.

Frequency of articles which contain words mother or/and father in the selected publications and the manner in which they depict a mother or a father

\begin{tabular}{|c|c|c|c|c|c|c|c|c|c|c|c|c|}
\hline & \multicolumn{2}{|c|}{$\begin{array}{c}\text { Večernji list } \\
1991\end{array}$} & \multicolumn{2}{|c|}{$\begin{array}{l}\text { Večernji list } \\
2011\end{array}$} & \multicolumn{2}{|c|}{$\begin{array}{c}\text { Vjesnik } \\
1991\end{array}$} & \multicolumn{2}{|c|}{$\begin{array}{c}\text { Vjesnik } \\
2011\end{array}$} & \multicolumn{2}{|c|}{$\begin{array}{c}\text { Bebe } \\
1992 / 93\end{array}$} & \multicolumn{2}{|c|}{$\begin{array}{l}\text { Bebe } \\
2012\end{array}$} \\
\hline & $\begin{array}{l}M \\
\text { (f) }\end{array}$ & $\begin{array}{l}F \\
\text { (f) }\end{array}$ & $\begin{array}{l}M \\
\text { (f) }\end{array}$ & $\begin{array}{l}F \\
\text { (f) }\end{array}$ & $\begin{array}{l}M \\
\text { (f) }\end{array}$ & $\begin{array}{l}F \\
(f)\end{array}$ & $\begin{array}{l}M \\
(f)\end{array}$ & $\begin{array}{l}F \\
\text { (f) }\end{array}$ & $\begin{array}{l}\mathrm{M} \\
\text { (f) }\end{array}$ & $\begin{array}{l}F \\
\text { (f) }\end{array}$ & $\begin{array}{l}\mathrm{M} \\
\text { (f) }\end{array}$ & $\begin{array}{l}F \\
\text { (f) }\end{array}$ \\
\hline Positive & 81 & 41 & 161 & 136 & 75 & 30 & 27 & 31 & 19 & 14 & 3 & 2 \\
\hline Negative & 13 & 41 & 54 & 70 & 13 & 16 & 14 & 20 & 0 & 0 & 0 & 0 \\
\hline Neutral & 168 & 108 & 261 & 224 & 116 & 81 & 143 & 103 & 76 & 29 & 67 & 18 \\
\hline Total & 262 & 190 & 476 & 430 & 204 & 127 & 184 & 154 & 95 & 43 & 70 & 20 \\
\hline
\end{tabular}

Legend: $\mathrm{M}$ - mother; $\mathrm{F}$ - father

Taking all three publications together, the proportion of positive, negative and neutral appearances of the word mother in the newspapers show a tendency towards less positive and more negative views in 2011 ( $\chi 2$ test $=10.70, \mathrm{df}=2, \mathrm{p}<.05$ ), while for fathers there was no statistically significant change $\left(\chi^{2}\right.$ test $\left.=1.64, \mathrm{df}=2, \mathrm{p}>.05\right)$ (Figures 1 and 2).

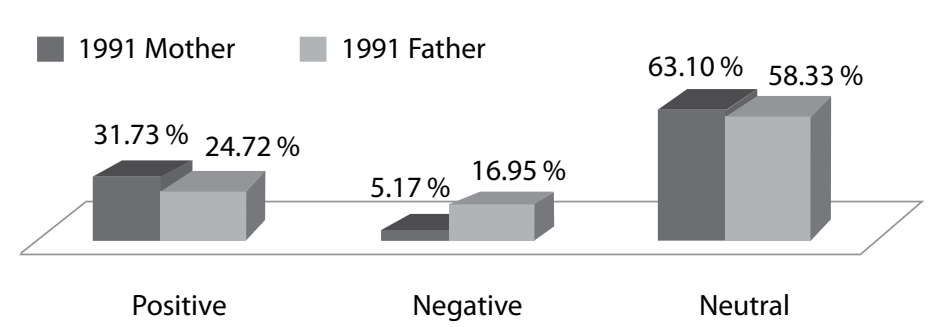

Figure 1. Comparison of the frequency of occurrence of words mother and father in a positive, negative or neutral context in newspaper articles in 1991 in percentages

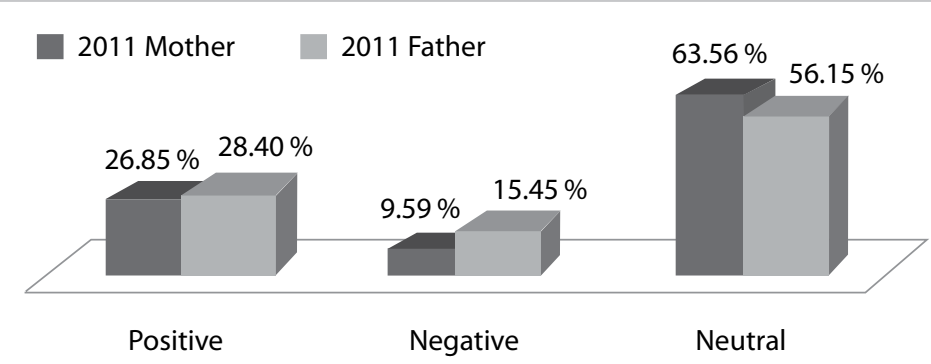

Figure 2. Comparison of the frequency of occurrence of words mother and father in a positive, negative or neutral context in newspaper articles in 2011 in percentages 
As can be seen from Table 2, the number of words mother and father in the titles increased in Večernji list in 2011 while in Vjesnik and Bebe it decreased. Regarding the occurrence of words mother and father on the front cover, the number of these words decreased in Vjesnik in 2011, and increased in Večernji list and Bebe (Table 3).

Table 2.

The frequency of occurrence of the words mother and/or father in the article title

\begin{tabular}{|c|c|c|c|c|c|c|}
\hline & $\begin{array}{c}\text { Večernji list } \\
1991\end{array}$ & $\begin{array}{l}\text { Večernji list } \\
2011\end{array}$ & $\begin{array}{c}\text { Vjesnik } \\
1991\end{array}$ & $\begin{array}{c}\text { Vjesnik } \\
2011\end{array}$ & $\begin{array}{c}\text { Bebe } \\
1992 / 93\end{array}$ & $\begin{array}{l}\text { Bebe } \\
2012\end{array}$ \\
\hline Mother & 54 & 130 & 46 & 18 & 11 & 4 \\
\hline Father & 40 & 139 & 17 & 14 & 3 & 1 \\
\hline $\begin{array}{l}\text { Both the mother } \\
\text { and the father }\end{array}$ & 1 & 12 & 4 & 1 & 1 & 0 \\
\hline
\end{tabular}

Table 3.

The frequency of occurrence of the words mother and/or father on the front cover of the publication

\begin{tabular}{|c|c|c|c|c|c|c|}
\hline & $\begin{array}{l}\text { Večernji list } \\
1991\end{array}$ & $\begin{array}{l}\text { Večernji list } \\
2011\end{array}$ & $\begin{array}{c}\text { Vjesnik } \\
1991 \\
\end{array}$ & $\begin{array}{c}\text { Vjesnik } \\
2011\end{array}$ & $\begin{array}{c}\text { Bebe } \\
1992 / 93\end{array}$ & $\begin{array}{l}\text { Bebe } \\
2012\end{array}$ \\
\hline Mother & 4 & 27 & 7 & 3 & 1 & 5 \\
\hline Father & 1 & 19 & 2 & 2 & 0 & 1 \\
\hline $\begin{array}{l}\text { Both the mother } \\
\text { and the father }\end{array}$ & 5 & 4 & 2 & 0 & 0 & 0 \\
\hline
\end{tabular}

In order to explain our results it is necessary to describe briefly the cultural context and events that occurred during the analysed periods. Firstly, Croatia is a young country formed after the secession from Yugoslavia in 1991, the year we selected to analyze. This year reflects the pre-war and wartime context prior to the secession. The main topic of daily newspapers was mainly the return of young Croatian soldiers to their homes. Their mothers had a leading role in the efforts to get their children back home. They formed a movement of mothers whose aim was to bring their sons home safely and their activities were very well covered in all daily newspapers in the country. This specific context has almost certainly had an impact on the selection of topics in the newspaper. However, from this analysis we can see how mothers and fathers were portrayed in the press in this context. Twenty years later, in the year 2011, people in Croatia lived their everyday lives in peace and Croatia represented a kind of a modern society but with fairly strong traditional gender values.

\section{Večernji list}

Although the manner of reporting in Večernji list and Vjesnik differs, both newspapers are very similar in their concept and focus mainly on an overview of economic news from the country and the world, events in the region, cultural and sports reviews. Still, Večernji list tends to be more sensational than Vjesnik. Večernji list reports more often about life of famous people (e.g. "Famous actress becomes a mother", or "Famous singer becomes a proud father"). Besides, Večernji list writes more about the problems of people in their everyday life, so the articles that focus on parents 
or parental behaviour are more common (e.g. "Some fathers and mothers are willing to pay a large sum of money for adequate babysitting", or "Mothers can stay with their children in children's wards in hospitals").

\section{Mothers in Večernji list}

In 1991 , mothers were mentioned in $64 \%$ of the articles in neutral terms, $31 \%$ of the articles depicted them in a positive manner, and $5 \%$ in a negative manner. The word mother often appeared in articles that talked about mothers who demanded that the Yugoslav army generals dismiss soldiers (their sons) from the army so that they could return home. It was a theme running throughout the whole year. As previously stated, the mothers had established a movement called the Wall of Love and their activities were reported almost on a daily basis. These mothers were described as brave, relentless, concerned, competent, loving their children, and prepared to do anything in order to bring their sons home safely. Mention of mothers in a negative manner refers to mothers neglecting or, for instance, killing their own children (e.g. "The mother had left her own child to die").

In 2011, both mothers and fathers were mentioned almost two times more in Večernji list than twenty years before. One possible explanation for this finding can be found in almost doubled number of pages compared to 1991. In addition, the frequency of appearance of the word mother in the titles of articles increased more than two times (Table 2), and the occurrence on the front cover of the paper increased almost seven times (Table 3). As already mentioned, in 1991, the war context prevailed and there was less coverage of the daily life topics, so this finding most probably reflects the time context.

In 2011, mothers were still most often mentioned in neutral terms (55\%), 34\% of the articles depicted them in a positive manner and $11 \%$ in a negative manner. Regarding the positive and negative depictions, we have found an increase in the relative frequency of negative descriptions of mothers compared to $1991\left(\chi^{2}=4.906\right.$, $\mathrm{df}=1, \mathrm{p}^{\prime}=3.841$ ). It seems that the increase of negative descriptions is a result of a greater sensitivity to the less obvious negative actions of mothers towards children (e.g. "Mother finds excuses to prevent the father from seeing the child" or "Mother leaves her child unattended").

In addition, early in 2011 several issues of Večernji list followed the story of a young couple whose child was about to be taken into custody by the Centre for Social Welfare. In these articles, both mother and father were described as persons living in poverty but as fully competent, full of love and care for their child. The implication being that they should be allowed to keep their child. Also, in 2011 there were more articles with advice and tips for mothers how to nurture their children and those which emphasized the importance of a mother in a child's life.

\section{Fathers in Večernji list}

Večernji list in 1991 mentioned fathers in 57\% of articles in a neutral way (e.g. "They told the father that we had to move away", or "His father testified in the process"), 
in $21.5 \%$ in a positive manner (e.g. "His father almost always accompanies him at tournaments"; "His father was an honest man"; "Father of three took maternity leave for each child and taught them to play chess"), and $21.5 \%$ in a negative manner (e.g. "His father was a hard nationalist"; "Father took part in the ritual murder of a child"). As can be seen from Table 1 word father in Večernji list in 1991 was less present in articles compared to the word mother. The reason for such results might be the fact that during the war time newspapers were more likely to portray men in the role of the warriors than in their fathers' role.

In $2011,52 \%$ of articles mentioned fathers in a neutral manner, $32 \%$ in a positive and $16 \%$ in a negative manner. Therefore, we could see that, in relation to the positive and negative descriptions, the number of positive mentions of fathers increased and the relative number of negative mentions decreased compared to $1991\left(\chi^{2}=6.354, \mathrm{df}=1\right.$, $\mathrm{p}^{\prime}=3.841$ ). In October 2011, there was an article on the topic of paternal involvement with children. This article emphasized that fathers were infrequently involved with their children although a small shift towards their increased involvement was noticed (e.g. "Fathers are playing with their children every fourth day but it is more than they did before"). In addition, several articles in 2011 focused on the issue of getting custody of the children and the problem of fathers in obtaining custody. It should be noted that in Croatia the custody of children is generally awarded to the child's mother even when the child declares that he or she wants to live with the father.

The results also show that the words mother and father are most frequently mentioned in Večernji list. This is expected regarding the orientation of the newspaper and the large number of articles. However, the proportion of mentioning fathers and mothers did not change in relation to 1991. Mother's role was obviously still more emphasized than the father's role. Nevertheless, the content analysis of the articles describing fathers in a positive way indicates that the consideration for the role and the importance of fathers is on the increase. Deven's (1991, as cited in Lamb, 1997) findings show that the articles describing men's faults are more frequent than the ones about their advantages. On the contrary, our research results showed that fathers, just as mothers, are described more frequently in a positive than in a negative way. However, the fact that the absolute frequency of negative descriptions of mothers and fathers has increased while the frequency of the positive description of mothers in 2011 has decreased seems to be a problem. It is a well known fact that bad news increase newspapers sales while pointing out the negative issues may stimulate the public to undertake action to rectify them. However, there is a risk that continuously bombarding the public with negative images may contribute to an increase in the public tolerance for negative behaviours and creating negative stereotypes of both fathers and mothers.

\section{Vjesnik}

\section{Mothers in Vjesnik}

In 1991, the word mother appeared in 204 articles. Mothers were mentioned in neutral terms in $57 \%$ of the articles, $37 \%$ of the articles depicted them in a positive 
manner and $6 \%$ in a negative manner (Table 1). Descriptions of mothers, regardless of whether they were positive, negative or neutral were mostly the same as in Večernji list. Positive descriptions talked about brave, tender and caring mothers, while negative descriptions referred to the mothers' negative characteristics or negative maternal behaviours.

In 2011, mothers were mentioned less often than in 1991 although the volume of the journal had increased. The reason probably lies in the fact that in 1991, the earlier mentioned movement of mothers was extremely important and newspapers reported on their actions almost on a daily basis. In 2011, Vjesnik reported more about the economic, commercial and political issues that were not closely related to the role of a mother or a father. Mothers were still more often mentioned in neutral terms (77\%), which was even more frequent than before. Positive description of mothers decreased from $37 \%$ to $15 \%$ and the negative increased from $6 \%$ to $8 \%$ compared to $1991\left(\chi^{2}=6.343, \mathrm{df}=1, \mathrm{p}^{\prime}=3.841\right)$.

\section{Fathers in Vjesnik}

As already mentioned, in 1991 men were more frequently presented in the role of brave warriors and protectors although it was sometimes mentioned that the brave warrior was also a father. Fathers were mentioned in a neutral manner in $64 \%$ of articles, in a positive manner in $24 \%$ and in a negative manner in $12 \%$ of articles. In the positive light, fathers were portrayed as people concerned with the safety of families and children and as important parts of the families (e.g. "When my father is beside me I'm not afraid of anything"; "We just want our father back"). In the context of everyday life, positive representation of fathers implies figures who contribute to the success of their children in the way that they convey their love for specific area of activity, or as a source of support to their children's work. One article brought interesting news about the American father of the year who was presented as the embodiment of paternity: strong, determined and courageous on the one hand, and soft, caring and full of love for their children on another. In a negative sense, which is as twice more often for fathers compared to mothers, fathers are portrayed as aggressive, alcoholics, neglectful or unreasonable persons.

In 2011, compared to 1991, the word father appeared in articles more often (Table 1). Fathers were mentioned in a neutral way in $67 \%$ of articles, in a positive way in a $20.1 \%$ and in a negative way in a $12.9 \%$ of the articles. Compared to 1991 , there is no significant change in fathers' portrayals considering the number of positive or negative presentations $\left(\chi^{2}=0.204, \mathrm{df}=1, \mathrm{p}^{\prime}=3.841\right)$. Nevretheless, reporting on fathers in a negative context is twice as frequent than on mothers, mostly through reports of crimes (e.g. "Father killed two persons") and through descriptions of the content of the award-winning films in which the theme of the negative role of the father in 2011 came to the fore. However, in the first half of 2011, the word father was often mentioned in a positive manner across the sports pages, thanks to the father of Janica 
and Ivica Kostelić1. In fact, journalists tended to emphasise his role as a father in Janica and Ivica's world's top achievement in skiing. Also, in 2011, two articles reported on the law that enables fathers to take parental leave, as well as the fact that at the time very few fathers used this option.

The frequency of words mother and father on the Vjesnik front cover and in the titles of articles was low for both analysed years. It was even lower in 2011 than in 1991. This reflects the fact that Vjesnik was predominantly political journal, so the roles of mothers and fathers had rarely been the topics it reported on.

\section{Bebe}

As stated earlier, unlike Večernji list and Vjesnik, which are daily newspapers, Bebe is a monthly magazine for parents. Its focus is on the care and nurturing of the child, and providing advice and support to the expecting mothers. Bebe provides comprehensive information on prenatal development, nutrition, infant care, disease prevention, as well as on the development of speech, and physical, social, emotional and cognitive development of a child. Given that Bebe is a specialized magazine, the articles are long and comprehensive, spanning several pages. Therefore, the number of articles in Bebe is smaller than in daily papers.

\section{Mothers and Fathers in Bebe}

As shown in Table 1, the word mother appeared in the articles several times more often than the word father. Also, both mothers and fathers were mentioned in Bebe most frequently in a neutral manner, and unlike in daily newspapers, there were no negative depictions of them. Such presentation seems logical given that Bebe is a magazine that advises and shows parents how to become better parents.

The content analysis of Bebe articles has shown several interesting things in relation to how the authors address their readers. The text usually begins by addressing the parents (e.g. "The parents should take care about..."), but further on, authors almost exclusively address mothers (e.g. "When buying a feeding bottle, mothers should keep in mind...”). Although the articles in 2012 still contained more advice to mothers, which is the reason why the word mother was more frequent than the word father, the words parent and caregiver were used increasingly. Therefore, the absolute frequency of words father and mother was lower in 2012 than ten years before. It is also interesting to note that articles in 1992/93 had somewhat patronizing tone, like in "every mother must know...". In 2012, such tone was changed. Mothers were addressed with respect (e.g. "Mothers know...") and given recommendations on what to do (e.g. "It would be good for mothers to know..."). Although two articles in 1992/93 stated that a child was not mother's only responsibility, that father and mother should together give a child warmth and security, and that it was important for father and mother to play with the

\footnotetext{
${ }^{1}$ Janica and Ivica Kostelić are world famous Croatian skiers who together won 11 Olympic medals. They express their gratitude for the success to the father who was their coach.
} 
child every day, several articles wrote that the warm relation and closeness with the mother were of crucial importance for the child. This reflects the scientific paradigm prevailing until 1970s. This paradigm was underpinned by the early psychoanalytic theories and Bowlby's attachment theory. In both theories mother is seen as the key mediator in child's socio-emotional development, and as Parke (1996) noticed, paternal role in child development was ignored for a long time because it was assumed that fathers were less important than mothers. However, twenty years later a shift from such view can be noticed in Bebe magazine. For example, one article in 2012 pointed out that "mother or father's warmth" was the most important for a child. An article on the prenatal development of children's senses recommended that fathers speak close to mother's stomach so that the child could develop trust in his voice. Three articles wrote about mother and father's joint care and involvement with the child. One issue had a several pages long article with 50 pieces of advice for daddies. The article featured on the front cover. Although the word mother was more frequent than the word father in the titles of the articles published in 2012, this frequency was almost three times less than in 1992 (Table 2). This could indicate that it is no longer a prevailing opinion that taking care of children is exclusively a maternal job. These findings indicate that the awareness of the need for the father's involvement is growing nowadays and that the magazine follows scientific trends. This is obviously an attempt to draw fathers out from a shadow, show them how to develop attachment to their child implying that maternal instinct is not inborn and that fathers have the same potential to develop paternal instinct. However, as we have assumed, mothers are mentioned more often than fathers in Bebe magazine articles. As already mentioned, Croatia is a traditional country and from the traditional perspective, mothers have a more important role than fathers in child development. Furthermore, it should be noted that the contemporary research shows that the role of a mother is the most important in building women's personal identity while fatherhood might be desirable but not so essential to the role of a man (Arendell, 2000). Therefore, it seems that the mother's role is far more important for women than the father's role for men (Čudina-Obradović \& Obradović, 2006). Having this in mind, it is understandable that the magazine "addresses" more frequently the mothers as potentially larger audience. This is probably the reason why the word mother appeared more often on the magazine front cover in 2011 (Table 3).

\section{Conclusion}

Results indicate more frequent mentioning of both mothers and fathers in 2011/12 compared to 1991/92, although the ratio of their mentioning remains unchanged. As we have suggested, in all the newspapers across time mothers are mentioned more often than fathers. Regarding the frequency of appearance of the words mother and father in the articles' titles, it can be seen that in 1991 the word mother appeared more often than the word father while in 2011 the appearance of both words in titles is quite similar. This may indicate a growing awareness of the importance of the father's role. 
The word mother appeared more frequently than the word father on the front cover in both analysed periods. In all journals, the words father and mother were most frequently used in a neutral way, approximately twice less frequently in a positive and the least frequently in a negative way. Yet, as we have assumed, fathers were more often described in a negative way. Večernji list had the highest frequency of the word father described in a negative way. Bebe magazine did not describe mothers and fathers in a negative way. The overall analysis of neutral, positive and negative descriptions in the papers shows that descriptions of mothers tended to be less positive and more negative in 2011 while for fathers no statistically significant difference in this respect was found.

Our results show that the public image of mother's and father's role is somewhat changing. Fathers are increasingly shown as co-parents. Richard Bowlby, contrary to his famous father John Bowlby, points out that both a father and a mother are equally important for the child's development, but their roles differ. Mother provides more care and nurture while father is in charge of stimulations and explorations. According to Richard Bowlby, a father and a mother both develop a primary attachment with the child who develops a dual attachment (Newland \& Coyle, 2010). Recent content analysis on 575 Parent's Magazine articles on fathering (1926-2006) has shown the shift in fathers' involvement from enjoyment to fulfilment (Milkie \& Denny, 2014).

The photographs of fathers carrying their babies and playing with them appear in media more and more often (Carpenter, 2002). Nevertheless, we are still in a transition period with a number of ambivalences and contradictions regarding the father's role (Castelain-Meunier, 2012).

Since the media have an impact on the formation and change of attitudes (McCall \& Stocking, 1982), reports on fathers and mothers in the newspapers should definitely send a more positive message about them. Media should encourage greater involvement of fathers, according to research trends that indicate the positive effects of fathers' involvement in childcare, as well as to support these arguments with research findings. The rationale for such behaviour lies in Jacobs and Eccless's (1985) findings which provide evidence that research reported in the media can indeed have an effect on the beliefs of people who are exposed to it. Newspapers can therefore continue to report on the negative behaviours of fathers and mothers, but it would be advisable that the same newspaper issue in which such report was published also publishes the article, written by an expert in the field, which could discuss the possible causes of the resulting situation and provide guidance for the prevention of such behaviour in the future.

We believe that daily newspapers in our sample are good indicators of the way the Croatian daily press writes about fathers and mothers. In fact, all the daily newspapers publish mainly the same news and report on them in a similar manner. Likewise, news programs in the electronic media (TV, radio, Internet) publish mainly the same content and report on them in a similar manner. Considering other specialized magazines for parents in Croatia, we assume that they are written in a similar way as the magazine 
Bebe is. Nevertheless, it could be of an interest for a future exploration to examine whether there is a difference in the manner they represent mothers and fathers as well as their roles in the upbringing of children between these specialized magazines. In addition, this study did not cover periodicals, as well as local newspapers, which due to the content and characteristics of the local community may have some deviation with respect to the observed findings. Therefore, future research might explore how fathers and mothers are presented in local newspapers. Likewise, we believe that the analysis of different types of television programmes broadcasting on the national level could provide deeper insight into the research topic.

\section{References}

Arendell, T. (2000). Conceiving and Investigating Motherhood: The Decade's scholarship. Journal of Marriage and Family, 62, 1192-1207.

Bebe (2011). Zašto oglašavati u časopisu Bebe?/online/. Retrieved on $7^{\text {th }}$ March 2014 from http://www.bebe.hr/marketing.html

Biller, H.B. (1993). Fathers and Families: Paternal Factors in Child Development. Connecticut: Auburn House.

Cabrera, N. J., Tamis-LeMonda, C. S., Bradley, R. H., Hofferth, S., \& Lamb, M. E. (2000). Fatherhood in the Twenty-First Century. Child Development, 71,127-136.

Carpenter, B. (2002). Inside the Portrait of the Family. Early Child Development and Care, 172 (2) 195-202.

Castelain-Meunier, C. (2002) The Place of Fatherhood and the Parental Role: Tensions, Ambivalence and Contradictions. Current Sociology, 50 (2) 185-201.

Čudina-Obradović, M., \& Obradović, J. (2006). Psihologija braka i obitelji. Zagreb: Golden marketing - Tehnička knjiga.

Clarke, L., \& O'Brien, M. (2004). Father Involvement in Britain: The Research and Policy Evidence. In R. D. Day, \& M. E. Lamb (Eds.), Conceptualizing and Measuring Father Involvement (pp. 39-60). New Jersey: LEA.

Gray, P.B., \& Anderson, K.G. (2010). Fatherhood: Evolution and Human Paternal Behavior. Cambridge, MA: Harvard University Press.

Jacobs, J.E., \& Eccles, J.S. (1985). Gender Differences in Math Ability: The Impact of Media Reports on Parents. Educational Researcher, 14 (20), 20-25.

Lamb, M.E. (1997). The Role of the Father in Child Development. New Jersey: John Willey and Sons Inc.

McCall, R.B., \& Stocking, S.H. (1982). Between scientists and the public. American Psychologist, 37, 985-995. 
Milkie, A.M., \& Denny K.E. (2014). Changes in the Cultural Model of Father Involvement: Descriptions of Benefits to Fathers, Children, and Mothers in Parents Magazine, 19262006. Journal of Family Issues, 35, 223-253.

Newland, L. A., \& Coyl, D. C. (2010). Fathers' Role as an Attachment Figures: An Interview with Sir Richard Bowlby. Early Child Development and Care, 180 (1-2), 25-32.

Parke, R.D. (1996). Fatherhood. Cambridge, MA: Harvard University Press.

Pleck, J.H. (1997). Paternal involvement: Levels, sources and consequences. In M.E. Lamb (Ed.), The role of the father in child development (3.ed., 66-103). New York: John Willey.

Randal, D.D., \& Mackey, W.C. (1986). The Role Image of the American Father: An Examination of a Media Myth. Journal of Comparative Family Studies, 17(3), 372-386.

Rudan, V., \& Nikolić, S. (1998). Otac u muškom razvoju. Socijalna psihijatrija, 26, 87-94.

Večernji list (2012). 2011 bila je godina uspjeha Večernjeg lista /online/. Retrieved on $7^{\text {th }}$ March 2014 from http://www.vecernji.hr/hrvatska/2011-bila-je-godina-uspjeha-vecernjeglista-370517

Vodopija, Z. (2006). Novinske agencije i dnevne novine. Medijska istraživanja, 12 (1), 131-135

\section{Tea Pahić}

Faculty of Teacher Education, University of Zagreb

Branch in Čakovec

Dr. Ante Starčevića 55, 40000 Čakovec, Croatia

tea.pahic@ufzg.hr

\section{Renata Miljević-Riđički}

Faculty of Teacher Education, University of Zagreb

Savska cesta 77, 10000 Zagreb, Croatia

renata.miljevic@ufzg.hr 


\section{Portreti majki i očeva u hrvatskim dnevnim novinama i časopisu za roditelje: danas i prije dvadeset godina}

\section{Sažetak}

Cilj provedenog istraživanja bio je ispitati je li, u proteklih dvadeset godina, došlo do promjene načina prikazivanja majki i očeva u hrvatskom tisku. Osobito nas je zanimalo kako roditelje prikazuju dnevne novine i časopisi za roditelje, kao i je li u novinama primjetan trend većeg uključenja očeva u odgoj djece. Kako bismo odgovorili na istraživačka pitanja, provedena je analiza sadržaja dvoje dnevnih novina i jednog časopisa za roditelje. Rezultati pokazuju da se javna slika majčinske i očinske uloge ponešto promijenila u odnosu na stanje prije dvadeset godina. Međutim, premda novine sve češće prikazuju očeve kao skrbnike djece, još smo uvijek $u$ tranzicijskom razdoblju u kojem postoje mnoge nedoumice $i$ neslaganja u pogledu uloge oca.

Ključne riječi: hrvatske dnevne novine; hrvatski mjesečni časopis; prikazivanje majki; prikazivanje očeva. 